\title{
Kierownictwo Sądu Okręgowego w Wilnie w okresie funkcjonowania Zarządu Cywilnego Ziem Wschodnich - szkice biograficzne
}

\section{Wprowadzenie}

„Z chwilą rozpoczęcia operacji Wojsk Polskich na Ziemiach Wschodnich [w 1919 r. - D.M.], na tereny te rozciągnięty został zarząd wojskowy. Wojsko polskie, zwycięsko wydzierając nieprzyjacielowi obszary dawnej Rzeczypospolitej Polskiej, posuwało się dalej na wschód. Za wojskiem w ślad kroczyła władza cywilna, która, wbrew zasadzie »inter arma silent togae«, zarządziła, by wymiar sprawiedliwości był oddany w ręce normalnych instytucji sądowych. Rozumiano, że nie wystarczy kraj odzyskać. Trzeba go utrzymać i dalszym pokoleniom przekazać, dając mu to, czego w owej chwili świat cały najwięcej był spragniony - praworządność i spokój”' . Dziewięćdziesiąt lat temu, w 1929 r., tymi słowami rozpoczął Kazimierz Petrusewicz swoją publikację dotyczącą pierwszego dziesięciolecia funkcjonowania sądownictwa na Kresach Wschodnich po odzyskaniu przez Polskę niepodległości. Pomimo znacznego upływu czasu od ukazania się tego wydawnictwa wiedza nasza o początkach wymiaru sprawiedliwości, jego tworzeniu i działalności na wspomnianym obszarze jest

${ }^{1}$ K. Petrusewicz: Dziesięciolecie sądownictwa polskiego na ziemiach wschodnich. Wilno 1929 , s. 1. 
wciąż skąpa. Choć mamy interesujące publikacje Joanny Gierowskiej-Kałłaur², Konrada Kalaty ${ }^{3}$, Małgorzaty Materniak-Pawłowskiej ${ }^{4}$ czy Mikołaja Tarkowskie$\mathrm{go}^{5}$, to wciąż brakuje całościowego, monograficznego ujęcia tego zagadnienia między innymi w okresie interesującym autorkę szczególnie, a mianowicie funkcjonowania Zarządu Cywilnego Ziem Wschodnich (dalej: ZCZW) - czyli w latach $1919-1920^{6}$.

Wspomniany ZCZW, różnie przez historyków określany (jako jednostka administracyjna, urząd czy twór quasi-państwowy ${ }^{7}$ ), powołany został przez Naczelnego Wodza w kwietniu 1919 r. w celu administrowania obszarami byłego Wielkiego Księstwa Litewskiego kolejno oswabadzanymi spod władzy bolszewickiej przez Wojsko Polskie. Sposób zorganizowania ZCZW został unormowany rozkazem Naczelnego Wodza z 12 maja 1919 r. Jak z niego wynikało, było to rozwiązanie przejściowe obowiązujące „do czasu uregulowania w drodze właściwej ustroju obszarów wschodnich, zajętych przez wojska polskie"s. Na czele ZCZW stał Komisarz Generalny Ziem Wschodnich. Był on mianowany i odwoływany przez Naczelnego Wodza na wniosek premiera. Terytorium podległe ZCZW podzielono na okręgi, które powoływano stopniowo w miarę postępów polskiej ofensywy. Były to okręgi ${ }^{9}$ : brzeski, wileński, wołyński ${ }^{10}$ i miński (powstały

2 J. Gierowska-Kałłaur: Władza sadownicza na terenie bytego Wielkiego Księstwa Litewskiego w czasach Zarzadu Cywilnego Ziem Wschodnich (1919-1920). W: Polska i jej wschodni sasiedzi w XX wieku. Studia i materiaty ofiarowane prof. dr. hab. Michałowi Gnatowskiemu w 70-lecie urodzin. Red. H. Konopka, D. Boćkowski. Białystok 2004.

${ }^{3}$ K. Kalata: Zarzad Cywilny Ziem Wschodnich w latach 1919-1920. Struktura organizacyjna i zarys działalności. „Czasopismo Prawno-Historyczne” 2003, T. 55, z. 2 (zwłaszcza pkt IV. Wymiar sprawiedliwości i jego funkcjonowanie).

${ }^{4}$ M. Materniak-Pawłowska: Ustrój sqdownictwa powszechnego w II Rzeczypospolitej. Poznań 2003; Eadem: Sadownictwa kresowego trudne początki (1919-1921). W: Studia z historii ustroju i prawa. Księga dedykowana Profesorowi Jerzemu Walachowiczowi. Red. H. O1szewski. Poznań 2002.

${ }^{5}$ M. Tarkowski: Adwokatura wileńska 1918-1939. Studium historyczno-prawne. Gdańsk 2014.

${ }^{6}$ O ZCZW powstała obszerna publikacja: J. Gierowska-Kałłaur: Zarząd Cywilny Ziem Wschodnich (19 lutego 1919-9 września 1920). Warszawa 2003.

7 Zob. ibidem, s. 5; A.J. Mielcarek: Podziaty terytorialno-administracyjne II Rzeczypospolitej w zakresie administracji zespolonej. Warszawa 2008, s. 42.

${ }^{8}$ Rozkaz Naczelnego Wodza WP z dnia 12 maja 1919 r. dotyczący organizacji zarządu cywilnego na obszarach wschodnich zajętych przez wojska polskie (,Dziennik Urzędowy ZCZW" [dalej: DzU ZCZW] 1919, nr 3, poz. 15).

${ }^{9}$ Ulegały one przez okres funkcjonowania ZCZW różnym modyfikacjom.

10 Zob. zarządzenie Komisarza Generalnego Ziem Wschodnich z dnia 7 czerwca 1919 r. dotyczące utworzenia Okręgów administracyjnych: wileńskiego, brzeskiego oraz Zarządu powiatów wołyńskich (DzU ZCZW 1919, nr 5, poz. 41); Zarządzenie Komisarza Generalnego Ziem Wschodnich z dnia 9 września 1919 r. dotyczące utworzenia okręgu administracyjnego wołyńskiego i uprawnień Komisarza Okręgowego Wołyńskiego (Dz ZCZW 1919, nr 17, poz. 153). 
najpóźniej we wrześniu 1919 r.) ${ }^{11}$. Kierowali nimi komisarze okręgowi (następnie naczelnicy okręgowi $)^{12}$. Niższym szczeblem administracji były powiaty z komisarzami powiatowymi (miejskimi) na czele (później starostami). Powiaty z kolei dzieliły się na mniejsze jednostki administracyjne - rejony, które obejmowały od 3 do 5 gmin samorządowych i kierowane były przez naczelników ${ }^{13}$. Centralnym urzędem w aparacie administracyjnym był z kolei Komisariat Generalny podporządkowany bezpośrednio Komisarzowi Generalnemu Ziem Wschodnich.

Zapowiedź zapewnienia „ładu i spokoju” mieszkańcom byłego Wielkiego Księstwa Litewskiego znalazła się już w słynnej odezwie Naczelnego Wodza Józefa Piłsudskiego do nich skierowanej ${ }^{14}$. Zadanie to do realizacji otrzymały tworzące się w ramach ZCZW organy wymiaru sprawiedliwości wspólnie $\mathrm{z}$ powstającymi równolegle organami bezpieczeństwa. Koordynacja prac w tym obszarze z ramienia urzędu centralnego - Komisariatu Generalnego - spoczęła na barkach Wydziału Sprawiedliwości i Kodyfikacji z redakcją „Dziennika Urzędowego", który wchodził w skład Sekcji (I) Spraw Ogólnych. Kierownikiem tej sekcji został wówczas Jan Klott. Z kolei szefem wspomnianego wydziału mianowano Mieczysława Mickiewicza. Nie na długo znalazł się on jednak w tej roli, gdyż we wrześniu 1919 r. dokonano reorganizacji w Komisariacie Generalnym i duże wydziały podniesiono do rangi sekcji. Tak też się stało i z Wydziałem Sprawiedliwości. Kierowanie nową sekcją — Sekcją Sprawiedliwości (V) przypadło Feliksowi Dutkiewiczowi ${ }^{15}$, a utworzonym w jej ramach Wydziałem Sądowym ostatecznie - Witoldowi Raczkiewiczowi ${ }^{16}$.

\section{Wileński wymiar sprawiedliwości pod $Z C Z W$}

Sądownictwo powszechne uruchomiono na podstawie Rozporządzenia Komisarza Generalnego Ziem Wschodnich z 15 maja 1919 r. o urządzeniu ogólnego sądownictwa na obszarach wschodnich ${ }^{17}$. Wymiar sprawiedliwości w myśl tego

${ }^{11}$ Rozporządzenie Komisarza Generalnego Ziem Wschodnich z dnia 12 września 1919 r. dotyczące utworzenia Okręgu Mińskiego i uprawnień Komisarza Okręgowego Mińskiego (DzU ZCZW 1919, nr 19, poz. 174).

${ }_{12}$ Zmiana w nazewnictwie urzędów nastąpiła 10 października $1919 \mathrm{r}$.

${ }_{13}$ Szerzej K. Kalata: Zarząd Cywilny..., s. 67-79.

${ }^{14}$ Ibidem, s. 64.

15 DzU ZCZW 1919, nr 20, poz. 195.

16 DzU ZCZW 1919, nr 34, poz. 399. Zanim Wydział Sprawiedliwości przekształcił się w Wydział Sądowy, kierował nim Kazimierz Głębocki (zwolniony w listopadzie 1919 r.). DzU ZCZW 1919, nr 20, poz. 195; DzU ZCZW 1919, nr 28, poz. 306.

${ }^{17}$ DzU ZCZW 1919, nr 4, poz. 22. 
rozporządzenia sprawowali sędziowie pokoju, sądy okręgowe i Sąd Apelacyjny. $\mathrm{W}$ przyjętych rozwiązaniach oparto się z pewnymi zmianami na modelu rosyjskim obowiązującym do tego momentu na ziemiach wschodnich. Językiem urzędowym sądownictwa uczyniono język polski z zastrzeżeniem, że strony mogły wnosić podania w językach krajowych i posługiwać się nimi przed sądem. Sędziowie pochodzili z nominacji Komisarza Generalnego Ziem Wschodnich. Przez niego także, zresztą jak wszyscy mianowani urzędnicy wymiaru sprawiedliwości, mogli być w każdej chwili odwołani. Takie rozwiązanie budziło jednak wątpliwości w zestawieniu z przepisem, który mówił o zasadzie niezawisłości sędziowskiej. Kandydaci na urzędy sądowe mieli odpowiadać ogólnym warunkom służby sądowej. Wymóg posiadania wykształcenia prawniczego mógł być wyjątkowo pominięty w odniesieniu do sędziów pokoju. Takie rozwiązanie stanowiło konsekwencję braku wystarczającej liczby wykwalifikowanych sędziów. W okresie uruchamiania kresowego wymiaru sprawiedliwości sięgnięto przede wszystkim po polskich adwokatów, którzy w przeciwieństwie do sędziów mogli przed wojną funkcjonować w swoim zawodzie na omawianym obszarze. Liczba ich w stosunku do potrzeb była niewystarczająca ${ }^{18}$. Stąd kolejnym odstępstwem, obok zatrudniania nieprawników, było zaangażowanie, przynajmniej tymczasowo, rosyjskiego personelu sędziowskiego. Sędziowie Rosjanie zobowiązani jednak zostali do uczęszczania na wykłady języka polskiego ${ }^{19}$. W myśl art. 15 rozporządzenia sędziowie przy objęciu urzędu składali osobie sprawującej nadzór służbowy na piśmie przyrzeczenia o spełnianiu swych obowiązków „wedle najlepszej wiedzy i sumienia”. Komisarz Generalny Ziem Wschodnich zarządzeniem z 14 października 1919 r. wprowadził dla sędziów rotę przysięgi służbowej ${ }^{20}$.

Sąd Okręgowy w Wilnie uruchomiono na podstawie rozporządzenia Komisarza Generalnego Ziem Wschodnich z 24 maja 1919 r., które jednocześnie wskazywało dzień 15 czerwca jako datę otwarcia sądu. W tym dniu odbyły się uroczystości inauguracyjne przy udziale licznych sądowników, przedstawicieli duchowieństwa, władz wojskowych, administracyjnych i municypalnych, jednak pracę sąd rozpoczął 1 lipca. Właściwość terytorialna sądu obejmowała pierwotnie powiaty: wileński, święciański, lidzki, oszmiański, nowogródzki²1 oraz część trockiego (miasto Troki, 8 gmin w całości i 4 gminy częściowo). Następnie,

${ }^{18}$ Przy uruchamianiu 4 sądów okręgowych i sądów pokoju potrzeba było, jak zauważył Petrusewicz, zmobilizować ponad 300 prawników, kiedy stan liczbowy palestry polskiej w okresie wojny na Kresach mógł dostarczyć ich zaledwie 109 (np. w Wilnie było to 25 adwokatów i 18 pomocników). Idem: Dziesięciolecie sądownictwa..., s. 2.

19 Powoływano ich na utworzone etaty aplikantów sądowych i obsadzano nimi stanowiska sędziów śledczych, gdyż tę ostatnią funkcję pełnić mogli wyłącznie prawnicy. M. Materniak-Pawłowska: Sąownictwa kresowego trudne poczatki..., s. 233.

${ }^{20}$ Zarządzenie Komisarza Generalnego Ziem Wschodnich z 14 października 1919 r. dotyczące roty przysięgi dla urzędników i adwokatów (DzU ZCZW 1919, nr 25, poz. 260).

${ }^{21}$ We wrześniu 1919 r. z części pow. nowogródzkiego utworzono pow. baranowicki, który włączono do właściwościowości Sądu Okręgowego w Mińsku. 
w miarę jak wojska polskie posuwały się coraz bardziej na wschód, kompetencje Sądu Okręgowego w Wilnie rozciągnięto na trzy jeszcze powiaty: wilejski, dziśnieński, brasławski ${ }^{22}$. W lipcu 1919 r. wileński okręg sądowy obejmował ok. $2 \mathrm{mln} 700$ tys. ha z ludnością sięgającą ok. 1,5 mln. Na jego czele stanął praktykujący przed I wojną światową adwokat przysięgły Adolf Zmaczyński. Wiceprezesami zostali zaś: Jan Buyko, Aleksander Proniewicz i Roman Wirszyłło.

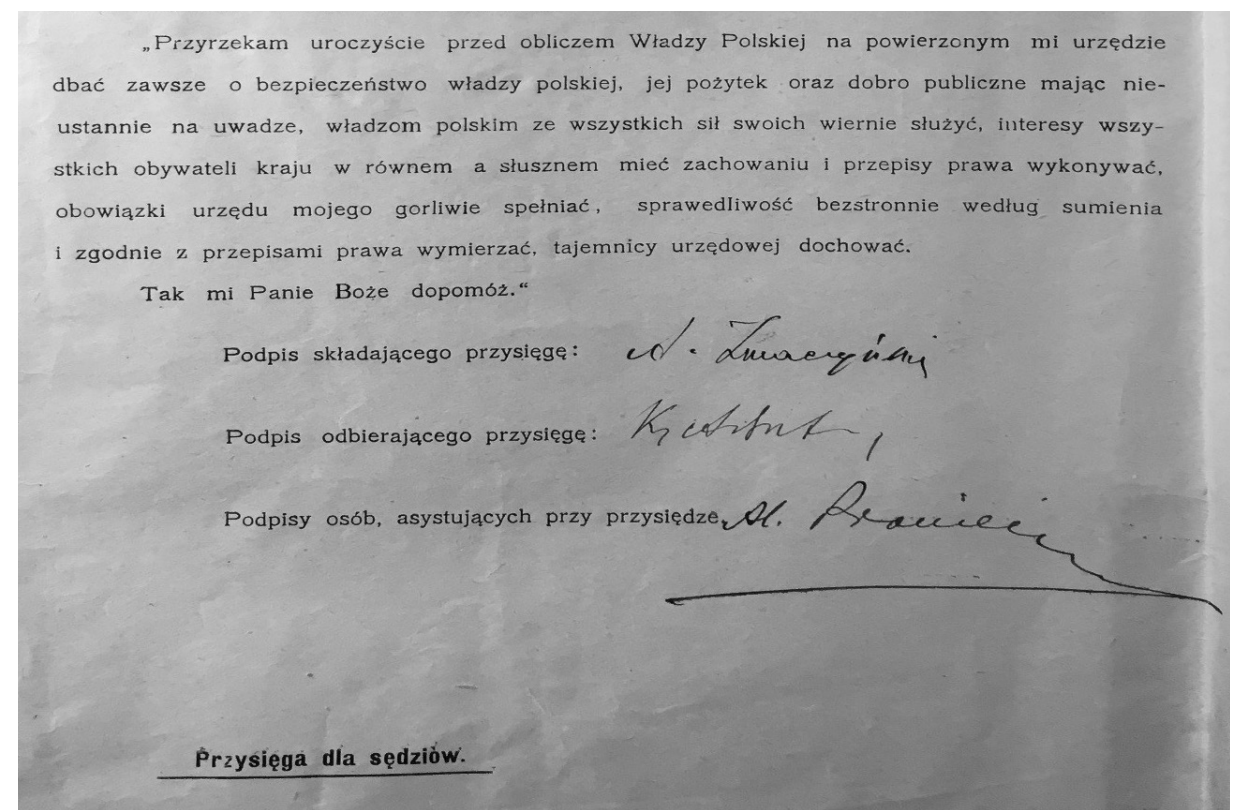

Fot. 1. Fragment protokołu z rotą przysięgi, którą 27 marca 1920 r. złożył prezes Zmaczyński

Źródło: Centralne Litewskie Archiwum Państwowe w Wilnie [dalej: LCVA], f. 129, ap.6, b. 1555.

Siedzibą Sądu Okręgowego w Wilnie uczyniono gmach instytucji sądowych na placu Łukiskim zbudowany w 1900 r. przez władze cesarskie z przeznaczeniem dla sądownictwa i powiększony na początku wojny przez dobudowanie nowego skrzydła ${ }^{23}$. Struktura organizacyjna przedstawiała się następują-

${ }^{22} \mathrm{~W}$ związku z ciągłymi zmianami obszaru okręgu sądowego systematycznie zwiększano etaty sądowe: we wrześniu 1919 r. o 2 podprokuratorów, 4 sędziów śledczych, 8 sędziów pokoju, 2 podsekretarzy, 2 kancelistów sądów pokoju, 4 komorników sądowych i 8 woźnych sądów pokoju; w listopadzie tr. o 1 sędziego sądu okręgowego, 1 podprokuratora, 2 sędziów śledczych, 4 sędziów pokoju, 1 podsekretarza, 1 kancelistę, 2 komorników sądowych, 4 sekretarzy, 4 kancelistów, 4 woźnych sądów pokoju.

${ }^{23}$ Biblioteka Litewskiej Akademii Nauk im. Eustachego i Emilii Wróblewskich w Wilnie [dalej: LMAVB], f. 29, vnt. 91, Opracowanie Aleksandra Jodziewicza dot. Sądu Okręgowego w Wilnie (1919-1928), [1928], k. 3. Warto wspomnieć, iż Aleksander Jodziewicz zaczynał swoją karierę w wileńskim wymiarze sprawiedliwości ZCZW jako podprokurator. 
co: Kancelaria Prezesa (utworzona w celu administracji okręgiem sądowym); Wydział I Karny pod przewodnictwem wiceprezesa A. Proniewicza; Wydział I Cywilny z przewodniczącym wiceprezesem J. Buyką ${ }^{24}$; Wydział II Karny, którym pokierował prezes A. Zmaczyński i Wydział II Cywilny - przewodniczący wiceprezes R. Wirszyłło. Nadto, wiosną 1920 r., uruchomiono Wydział Hipoteczny, w którym zatrudniono 20 stałych pracowników. W związku z tym, że wiceprezes Wirszyłło został w marcu tego roku pisarzem hipotecznym przy wileńskim sądzie okręgowym, jego miejsce zajął już do końca istnienia ZCZW (wrzesień 1920 r.) sędzia Adam Kondracki²5, w latach 1922 -1929 sędzia Sądu Najwyższego w Warszawie ${ }^{26}$.

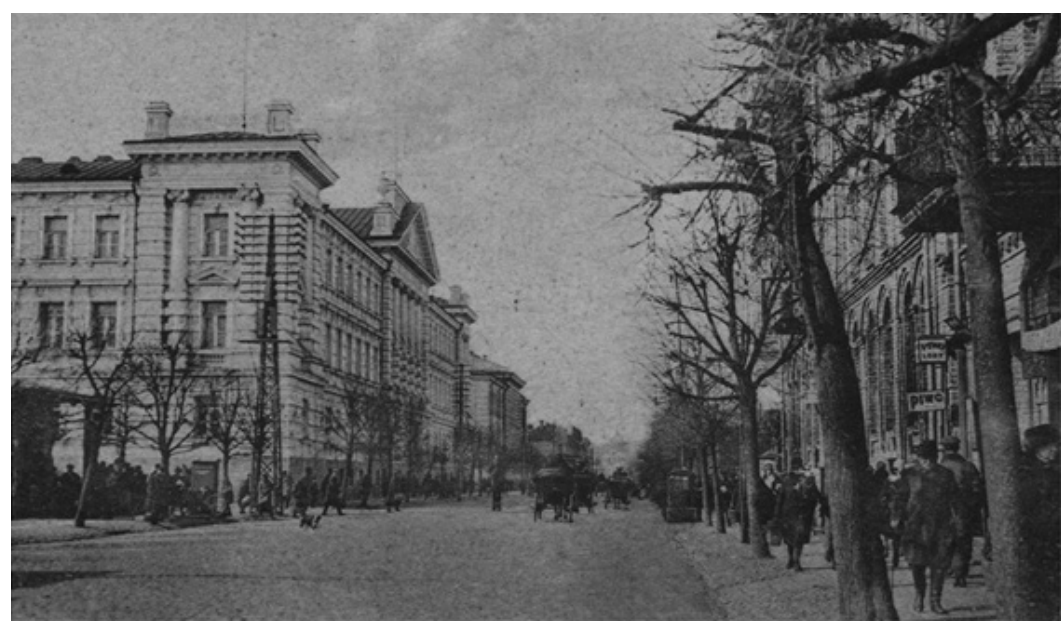

Fot. 2. Gmach (po lewej) Sądu Okręgowego w Wilnie (b.d.)

Źródło: Narodowe Archiwum Cyfrowe, sygn. 1-U-7599.

W składzie Sądu Okręgowego w Wilnie przedstawionym w „Dzienniku Urzędowym ZCZW" w lipcu 1919 r., poza wspomnianymi 4 sędziami ze ścisłego kierownictwa, znaleźli się również sędziowie: Bohdan Achmatowicz, Julian Bądzkiewicz, Stanisław Bohusz, Julian Kozłowski, Stanisław Łopaciński, Wincenty Łuczyński, Bogusław Osuchowski, Józef Witold Sokołowski, Józef Jarosław Wilkiewicz ${ }^{27}$. Skład ten w przeciągu roku funkcjonowania wileńskiego

${ }^{24}$ Do właściwości terytorialnej dwóch pierwszych wydziałów należały: miasto Wilno oraz powiaty: wilejski i dziśnieński.

${ }^{25}$ LMAVB, f. 29, vnt. 91, Opracowanie Aleksandra Jodziewicza..., k. 4. Niestety, nie udało mi się dotrzeć do wileńskich akt osobowych sędziego Kondrackiego.

${ }^{26}$ Wiadomo, że w październiku 1920 r. został sędzią Sądu Apelacyjnego w Lublinie. „Dziennik Urzędowy Ministerstwa Sprawiedliwości” 1921, nr 3. Z dniem 30 czerwca 1929 r. przeniesiony w stan spoczynku na skutek podania. „Ruch Służbowy. Dodatek do Dziennika Urzędowego Ministerstwa Sprawiedliwości” 1929, nr 21.

${ }^{27}$ DzU ZCZW 1919, nr 9, poz. 86. 
wymiaru sprawiedliwości ZCZW kilkukrotnie ulegał modyfikacjom ${ }^{28}$. Ostatecznie, kiedy doszło do letniej ofensywy bolszewickiej, część z nich (między innymi sędziowie: Kozłowski, Łuczyński, Gustaw Około-Kułak) wzięła udział w walce z najeźdźcą, wstępując do Wojska Polskiego. Wiązało się to z decyzją władz ZCZW o likwidacji Sądu Okręgowego w Wilnie, którą do realizacji prezes Adolf Zmaczyński otrzymał 1 sierpnia $1920 \mathrm{r}^{29}$. Likwidacja rozpoczęta 12 sierpnia zakończyła się ostatecznie 18 listopada $1920 \mathrm{r}^{30}$.

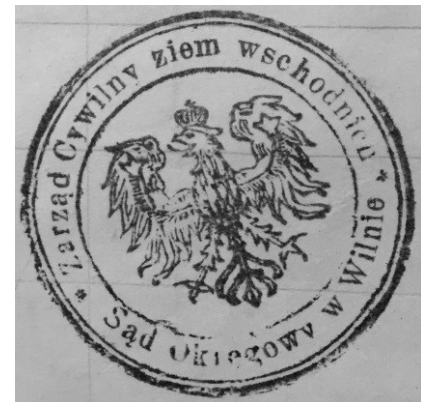

Fot. 3. Pieczęć Sądu Okręgowego w Wilnie (1919 r.)

Źródło: LCVA, f. 127, ap. 1, b. 3.

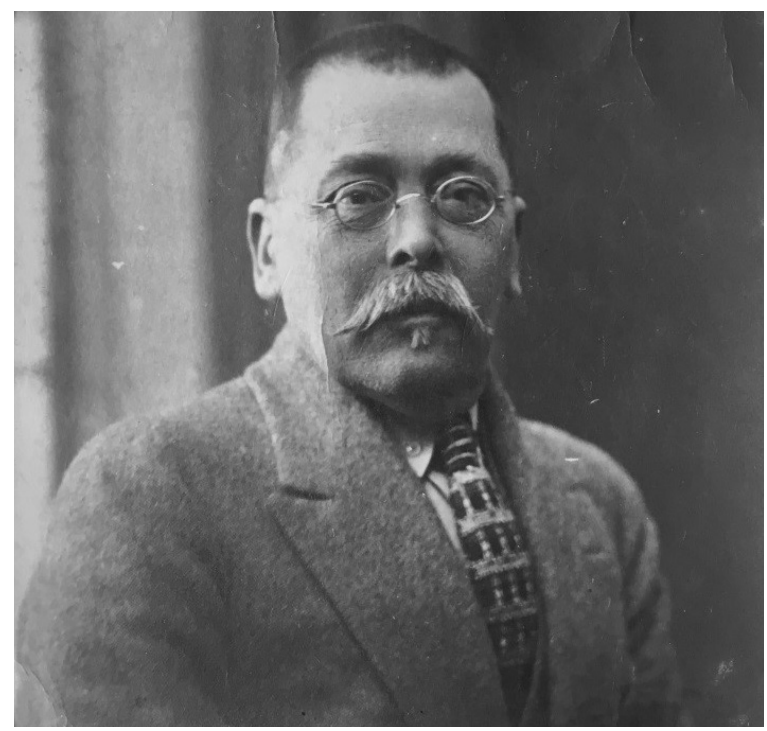

Fot. 4. Adolf Zmaczyński (1861—1926)

${ }^{28}$ Zob. J. Gierowska-Kałłaur: Władza sqadownicza..., s. 73.

${ }^{29}$ LCVA, f. 129, ap. 1, b. 2835, Pismo kierownika Sekcji Sprawiedliwości ZCZW do prezesa Sądu Okręgowego w Wilnie, 1 VIII 1920, k. 2.

${ }^{30}$ LCVA, f. 129, ap. 1, b. 2840, Pismo prezesa Sądu Okręgowego w Wilnie do Komisji Likwidacyjnej, 18 XI 1920, k. 41. 
Urodził się 22 stycznia 1861 r. w Wilnie ${ }^{31}$. Jego ojcem był Jan Zmaczyński, a matką Julia z Kowalskich. Ukończył Wydział Prawa Uniwersytetu Petersburskiego ze stopniem kandydata praw. W 1887 r. rozpoczął pracę jako pomocnik adwokata, a następnie (1892 r.) jako adwokat przysięgły ${ }^{32}$. W tej funkcji w roku 1911 objął stanowisko radcy prawnego magistratu w Wilnie, które zwolniło się po Restytucie Sumoroku (ten znany wileński adwokat przejął wówczas kierownictwo Bankiem Ziemskim w tym mieście) ${ }^{33}$. Brak informacji jak długo je piastował. Wiadomo, że posadę po nim otrzymał adwokat przysięgły Maksymilian Maliński. Kiedy wybuchła I wojna światowa i pod patronatem wiceprezydenta Wilna Konrada Niedziałkowskiego narodziła się koncepcja wypracowania wspólnego stanowiska różnych polskich ugrupowań partyjnych w kwestii stosunku do Rosji w zaistniałej sytuacji konfliktu zbrojnego, Adolf Zmaczyński znalazł się w nielicznej grupie osób opowiadających się za opcją prorosyjską ${ }^{34}$. W latach 1919-1921 prezes Sądu Okręgowego w Wilnie ${ }^{35}$. Mianowany przez Komisarza Generalnego Ziem Wschodnich 12 czerwca $1919 \mathrm{r}^{36}$. Zwolniony ze stanowiska na własną prośbę ${ }^{37}$. Dnia 31 maja 1921 r. mianowany notariuszem przy Kancelarii Hipotecznej tego sądu ${ }^{38}$. Urzędowanie rozpoczął 21 czerwca tego roku i kontynuował aż do śmierci ${ }^{39}$. W czasie jego nieobecności w kancelarii (urlop, choroba) jego obowiązki notarialne wykonywali Kazimierz Jacynicz i Bolesław Józefowicz ${ }^{40}$.

31 Wileński stownik biograficzny: suplement. Oprac. M. Jackiewicz. Bydgoszcz 2012, s. 325. Por. Wileński stownik biograficzny. Red. H. Dubowik, J. Malinowski. Bydgoszcz 2008, s. 593.

${ }^{32}$ LCVA, f. 129, ap. 6, b. 1555, Wykaz stanu służby Adolfa Zmaczyńskiego, b.d., k. 1-2.

${ }^{33}$ W kancelarii Zmaczyńskiego w latach 1907-1912 aplikację odbywał syn Restytuta Sumoroka - Leon. M. Tarkowski: Adwokatura wileńska..., s. 58-59.

${ }^{34}$ Z. Solak: Między Polska a Litwą. Życie i działalność Michała Römera 1880-1920. Kraków 2004, s. 240.

35 W czasie ewakuacji sądu latem 1920 r. odpowiadał za jego likwidację, a w związku z powołaniem na stanowisko doradcy prawnego(?) ustąpił 24 września tr. z funkcji prezesa. LCVA, f. 129, ap. 1, b. 2840, Raport Adolfa Zmaczyńskiego, [wrzesień 1920], k. 56; Mianowany prezesem Sądu Okręgowego w Wilnie przez Naczelnego Dowódcę Wojsk Litwy Środkowej 26 listopada 1920 r. LCVA, f. 127, ap. 7, b. 3430, Wykaz stanu służby Adolfa Zmaczyńskiego, b.d., k. 27.

${ }^{36}$ Dokument mianowania - kopia w zbiorach autorki.

${ }^{37}$ LCVA, f. 127, ap. 7, b. 3430, Odpis dekretu Naczelnego Dowódcy Wojsk Litwy Środkowej, [maj 1921], k. 23.

${ }^{38}$ LCVA, f. 129, ap. 6, b. 1555, Wyciąg z księgi rozporządzeń prezesa Sądu Apelacyjnego w Wilnie, [1921], k. 9.

${ }^{39}$ LCVA, f. 129, ap. 6, b. 1555, Pismo A. Zmaczyńskiego do prezesa Sądu Okręgowego w Wilnie, 21 VI 1921, k. 12. Jak wspomniał jego wnuk, również Adolf, prezes Zmaczyński w 1921 r., co było zaskakujące, dostał urzędowe pismo nadające mu polskie obywatelstwo. Zob. „Opowieść o patriotach” https://gdansk.gosc.pl/doc/1350339.Opowiesc-o-patriotach [dostęp: 6.03.2019].

${ }^{40}$ LCVA, f. 129, ap. 6, b. 1555, Pismo A. Zmaczyńskiego do prezesa Sądu Okręgowego w Wilnie, 11 VIII 1921, k. 17; LCVA, f. 129, ap. 6, b. 1555, Pismo A. Zmaczyńskiego do preze- 
Był członkiem Rady Wileńskiego Banku Handlowego ${ }^{41}$. Zmarł 10 kwietnia 1926 r. w Wilnie ${ }^{42}$ i tu został też pochowany (Cmentarz Bernardynów). Był dwukrotnie żonaty ${ }^{43}$. Ze związku małżeńskiego z Marią Jankowską (zawartego 22 lipca 1914 r. w Wilnie) miał córkę Marię (ur. 1908), a z Antoniną Daniłowicz 2 dzieci: Adolfa (ur. 1912) i Wandę (ur. 1915).

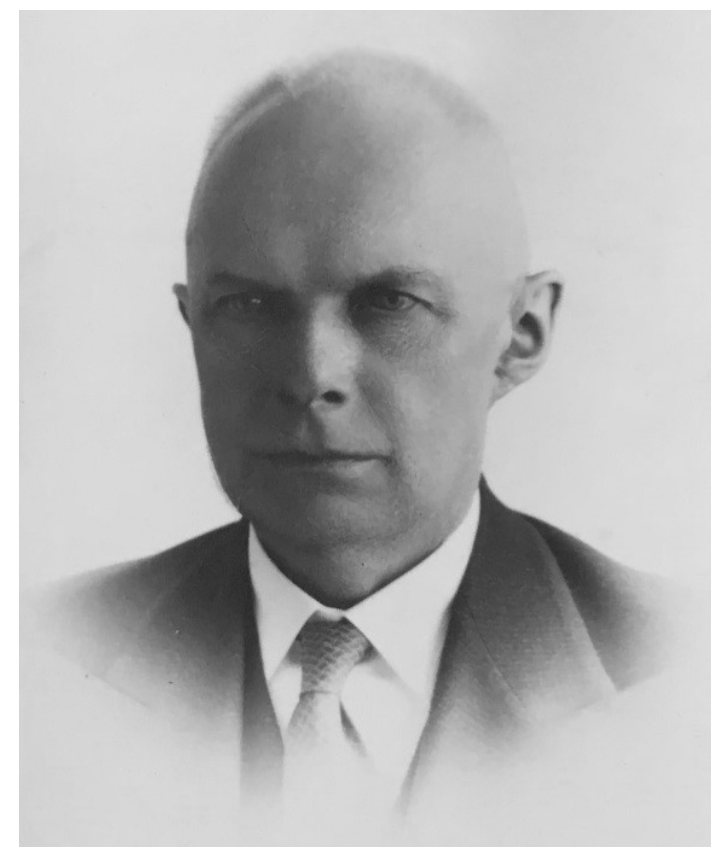

Fot. 5. Jan Buyko (1872-po 1939)

Urodził się 12 maja 1872 r. w Wilnie ${ }^{44}$. Jego ojcem był Tadeusz Buyko. Matka pochodziła z rodziny Cywińskich. Studiował na Wydziale Prawa Uniwersytetu w Moskwie, gdzie otrzymał dyplom I stopnia. Jeden semestr studiował również na Uniwersytecie w Berlinie. Karierę zawodową rozpoczął 1 września 1895 r. jako pomocnik adwokata. Po pięciu latach praktyki został adwokatem przysięgłym (4 listopada 1900 r.). Do wybuchu I wojny światowej, przez 8 lat, był również radnym miasta Wilna. Służbę w sądownictwie zapoczątkował

sa Sądu Okręgowego w Wilnie, 9 XI 1921, k. 26; LCVA, f. 129, ap. 6, b. 1555, Pismo A. Zmaczyńskiego do prezesa Sądu Okręgowego w Wilnie, 1 II 1923, k. 50.

${ }^{41}$ Nekrolog. „Dziennik Wileński”, 14.04.1926.

${ }^{42}$ LCVA, f. 127, ap. 7, b. 3430, Pismo prezesa Sądu Okręgowego w Wilnie do prezesa Sądu Apelacyjnego w Wilnie, 12 IV 1926, k. 18.

${ }^{43}$ Informacja przekazana autorce przez wnuka sędziego Zmaczyńskiego - Adolfa Zmaczyńskiego.

${ }^{44}$ Por. Wileński słownik biograficzny: suplement..., s. 53. Ochrzczony w kościele św. Ducha w Wilnie. 
akt nominacyjny z 12 czerwca 1919 r. Na jego mocy został mianowany przez Komisarza Generalnego Ziem Wschodnich na stanowisko wiceprezesa Sądu Okręgowego w Wilnie. Urząd złożył 16 listopada 1922 r. i z dniem następnym rozpoczął urzędowanie jako notariusz przy Kancelarii Hipotecznej Sądu Okręgowego w Wilnie. Zwolniony 15 listopada 1933 r. ponownie został mianowany notariuszem przy Wydziale Hipotecznym tegoż sądu w dniu 9 grudnia 1933 r. $^{45}$. Był prezesem Rady Notarialnej w Wilnie ${ }^{46}$. W październiku 1929 r. otrzymał Medal Dziesięciolecia Odzyskanej Niepodległości, w maju 1938 r. został z kolei odznaczony przez prezesa Sądu Apelacyjnego w Wilnie, Józefa Przyłuskiego, Brązowym Medalem za Długoletnią Służbę ${ }^{47}$. W środowisku wileńskim cieszył się powszechnym zaufaniem. Pozytywną opinię wystawili mu między innymi wiceprezes Banku Polskiego Jan Piłsudski, dziekan Rady Adwokackiej Marian Strumiłło czy senatorowie Zygmunt Jundziłło i Witold Abramowicz ${ }^{48}$. W latach 1936 - 1938 był członkiem Komitetu Redakcyjnego „Przeglądu Notarialnego”49. Ze związku małżeńskiego z Zofią Buszyńską, zawartego 14 października $1901 \mathrm{r}$. w Wilnie, miał 2 dzieci: Janinę (ur. 1902) i Zygmunta (ur. 1904).

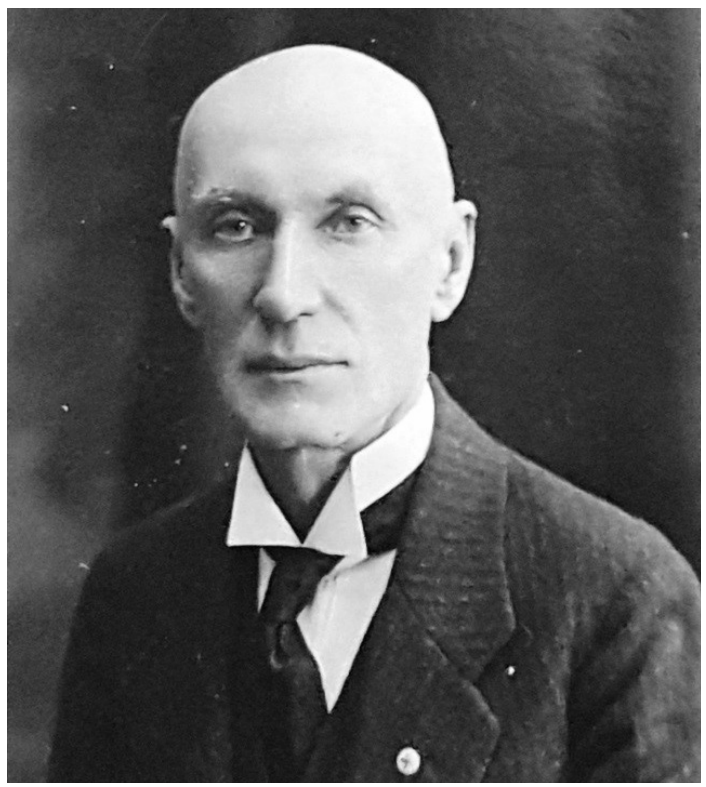

Fot. 6. Aleksander Proniewicz (1858-1926)

${ }^{45}$ LCVA, f. 127, ap. 7, b. 330, Wykaz stanu służby Jana Buyki, b.d., k. 1-2.

${ }^{46}$ Wybory do Rad Notarialnych. „Palestra” 1936, nr 7-8, s. 649.

${ }^{47}$ LCVA, f. 127, ap. 7, b. 330, Pismo prezesa Sądu Apelacyjnego w Wilnie do Jana Buyki, 8 X 1929, k. 8; Ibidem, Dyplom, 7 V 1938, k. 9.

${ }^{48}$ LCVA, f. 127, ap. 7, b. 330, Pismo prezesa Sądu Apelacyjnego w Wilnie do Ministerstwa Sprawiedliwości w Warszawie, 28 XI 1933, k. 20.

49 Zob. Komitet Redakcyjny. „Przegląd Notarialny” 1948, nr 1, s. 2. 
Urodził się 23 listopada 1858 r. w Grodnie ${ }^{50}$. Jego ojcem był Andrzej Proniewicz. Matka pochodziła z rodziny Ejsmontów. Absolwent Wydziału Prawa Uniwersytetu Warszawskiego. Dnia 4 września 1883 r. został przyjęty na służbę sądową jako aplikant przy prokuratorze Sądu Okręgowego w Kielcach. Przez tego prokuratora po dwóch latach mianowany został sekretarzem. Dnia 15 kwietnia 1887 r. przejął obowiązki sędziego śledczego 2 Dońskiego Okręgu Ust.-Miedwiedickiego Sądu Okręgowego, a 23 lutego 1891 r. objął stanowisko podprokuratora tegoż sądu. W maju 1893 r. przeniesiony został do Sądu Okręgowego w Woroneżu, skąd 7 lipca 1906 r. trafił do Sądu Okręgowego w Siedlcach $^{51}$. Z Siedlcami związany był do 1915 r., kiedy to w związku z wojną doszło do ewakuacji sądu do Rosji, najpierw jako sędzia, a następnie (5 października 1908 r.) jako notariusz przy Kancelarii Hipotecznej Sądu Okręgowego ${ }^{52}$. Rozkazem Tymczasowego Rządu w Rosji 11 lutego 1917 r. miał zostać zaliczony do Ministerstwa Wojny i mianowany „radcą prawnym 4 komisji frontu zachodniego"53. W 1918 r. powrócił i w niepodległej Polsce, od Ministra Sprawiedliwości, 23 grudnia otrzymał nominację na sędziego Sądu Okręgowego w Kaliszu, gdzie orzekał tylko pół roku. W związku bowiem z realizacją koncepcji tworzenia na Kresach Wschodnich polskiego sądownictwa 12 czerwca 1919 r. podjął się zadania współuczestniczenia $\mathrm{w}$ tym przedsięwzięciu, zostając $\mathrm{z}$ nominacji Komisarza Generalnego Ziem Wschodnich wiceprezesem Sądu Okręgowego w Wilnie. W lipcu 1921 r. awansował, przejmując ster nad tym sądem. Rok wcześniej otrzymał też zadanie przewodniczenia Sądowi Doraźnemu w Wilnie. Dalsza ścieżka zawodowa zaprowadziła go do Pabjanic, gdzie na mocy wniosku nominacyjnego Ministra Sprawiedliwości z 5 lipca 1923 r. został notariuszem w łódzkim okręgu sądowym, którym był do końca życia. Obowiązki prezesa Sądu Okręgowego w Wilnie złożył 11 sierpnia 1923 r., przekazując je sędziemu Adamowi Murza-Murziczowi ${ }^{54}$. W tym samym jeszcze roku współtworzył statut Towarzystwa Miłośników Historii Reformacji Polskiej im. Jana Łaskiego w Wilnie ${ }^{55}$. Wymownym podsumowaniem działalności sędziego Proniewicza był artykuł o charakterze pożegnalnym opublikowany w „Dzienniku Wileńskim” 7 sierpnia 1923 r. Autor podpisujący się inicjałami A.J. napisał w nim, że ustąpienie prezesa $\mathrm{z}$ sądownictwa wileńskiego stwarza $\mathrm{w}$ nim „b[ardzo] znaczną, trudną

${ }^{50}$ Wileński stownik biograficzny: suplement..., s. 243.

${ }^{51}$ A. Bereza: Sadownictwo siedleckie. Tradycje i wspótczesność. Warszawa 2010, s. 71.

${ }^{52}$ LCVA, f. 127, ap. 7, b. 2421, Wykaz stanu służby Aleksandra Proniewicza, b.d., k. 9-10.

${ }^{53}$ Informacja przekazana autorce przez wnuczkę sędziego Proniewicza - Barbarę Langiewicz-Mathis.

${ }^{54}$ LCVA, f. 127, ap. 7, b. 2421, Pismo prezesa Sądu Apelacyjnego w Wilnie do prezesa Sądu Okręgowego w Wilnie, 8 VIII 1927, k. 20.

${ }_{55}$ P. Dąbrowski: Towarzystwo Miłośników Historii Reformacji Polskiej im. Jana Easkiego - geneza, struktura prawna i działalność. „Odrodzenie i Reformacja w Polsce” 2017, T. 61, s. 274. 
do zapełnienia lukę", bowiem ,jako bardzo dobry Polak i prawnik, położył na swych stanowiskach w Wilnie poważne zasługi, zwłaszcza w okresach dwukrotnej organizacji sądów (w latach 1919 i 1920)"56. Zmarł w 1926 r. w Pabjanicach. Ze związku małżeńskiego z Zofią Marią Schmidt, zawartego 16 listopada 1882 r. w Warszawie, miał 16 dzieci, z czego 8 dożyło dorosłości: Sobiesław Andrzej (ur. 1883), Władysław (ur. 1885), Wanda Maria (ur. 1887), Wiktoria (ur. 1889), Jerzy (ur. 1892), Łucja (ur. 1896), Czesław (ur. 1899) i Maria (ur. 1902).

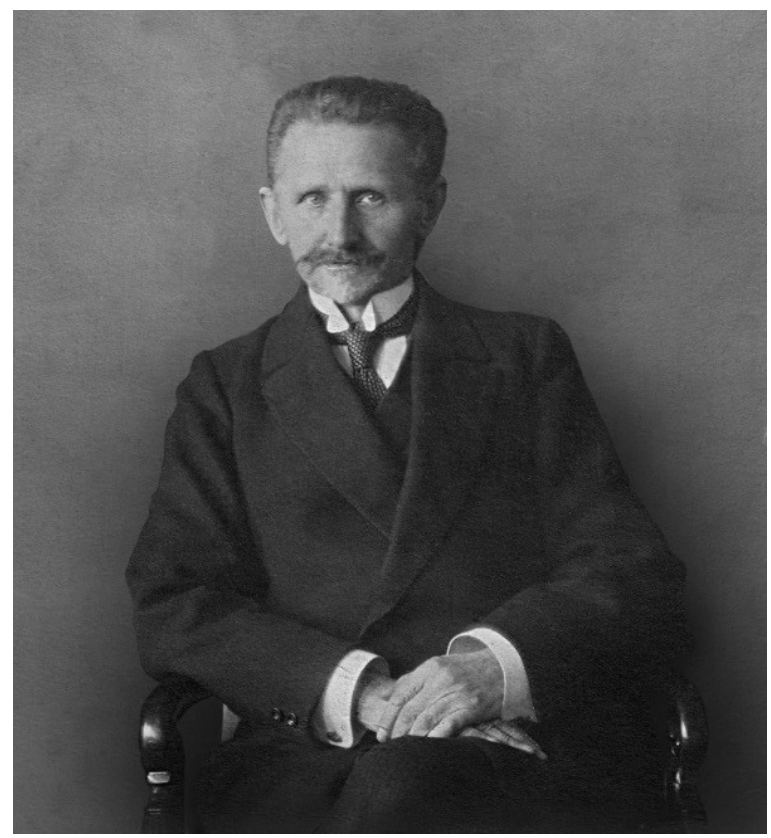

Fot. 7. Roman Grzegorz Wirszyłło (1864-1945)

Urodził się 28 lutego 1864 r. w majątku Medyngiany powiatu telszewskiego ziemi kowieńskiej. Jego ojcem był Cezary Wirszyłło, a matką Grasylda z Mitkiewiczów. Absolwent Wydziału Prawa Uniwersytetu Petersburskiego. Karierę prawniczą rozpoczął 8 lipca 1888 r. jako podsekretarz przy kowieńskim sądzie okręgowym, a następnie (kolejno) jako podsekretarz i sekretarz przy ryskim sądzie okręgowym (od 2 listopada 1889 r. do 10 czerwca 1893 r.). Stąd trafił do ekaterynodarskiego sądu okręgowego na stanowisko sędziego śledczego i dalej podprokuratora. Ścieżkę zawodową sędziego zaczął 23 listopada 1902 r. od Sądu Okręgowego w Baku. Kontynuował ją (od lipca 1906 r.) w Sądzie Okręgowym w Woroneżu aż do przewrotu bolszewickiego. W 1904 r. złożył też egzamin i uzyskał tytuł notariusza. Służbę w niepodległej Polsce podjął 25 lutego 1919 r., objął na krótko stanowisko radcy prawnego przy Zarządzie Wojskowym Ziem

${ }^{56}$ Wyjazd p. A. Proniewicza, Prezesa Sądu Okręgowego. „Dziennik Wileński”, 7.08.1923. 
Wschodnich, a następnie ZCZW. Jako doświadczonemu już sędziemu 15 czerwca 1919 r. powierzono mu funkcję wiceprezesa Sądu Okręgowego w Wilnie. Piastował ją do marca 1920 r., kiedy to otrzymał od Komisarza Generalnego Ziem Wschodnich nominację na urząd Pisarza Hipotecznego przy Sądzie Okręgowym w Wilnie ${ }^{57}$. Urząd ten złożył 15 maja $1924 \mathrm{r}^{58}$. Będąc jeszcze urzędnikiem ZCZW, 10 sierpnia 1919 r. otrzymał od Komisarza Generalnego Ziem Wschodnich delegację jako główny komisarz do zorganizowania i sporządzenia spisu ludności na trenach ziem wschodnich, „ewentualnie wyborów przedstawicieli’"59. Dnia 5 listopada 1924 r. został wpisany na listę adwokatów Okręgu Sądu Apelacyjnego w Wilnie ${ }^{60}$. Zmarł 19 grudnia 1945 r. w majątku Skała. Pochowany został na cmentarzu w Niemenczynie 10 dni później ${ }^{61}$. Ze związku małżeńskiego z Ludmiłą z Tejchmanów, zawartego 30 kwietnia 1892 r. w Rydze, miał 7 dzieci: Gustaw Wacław (ur. 1894), Tadeusz Zygmunt (ur. 1898), Henryk Florian (ur. 1901), Zygmunt Marian (ur. 1903), Irena Zofia (ur. 1904) oraz Nina i Stanisław, którzy zmarli w wieku dziecięcym.

\section{Zakończenie}

„Sąd Apelacyjny [w Wilnie] składał się albo z przedwojennych wybitnych adwokatów, którzy z przyczyny swej polskiej narodowości nie mogli pracować w sądownictwie w kraju, a do Rosji nie chcieli wyjechać, albo z sądowników zatrudnionych w wyższych sądach na terenie przedwojennej Rosji, również Polaków. Byli to ludzie o najwyższym poziomie etycznym, umysłowym, fachowym i kulturalnym, znakomici prawnicy, którzy w każdym czasie i miejscu zawsze byliby wzorem i ozdobą każdego sądu i sądownictwa. Byli to ludzie, przed którymi gdy się broniło, człowiek wiedział, że przy rozstrzyganiu sprawy będą oni powodowali się najusilniejszym dążeniem do prawidłowego jej rozstrzygnięcia, a za punkt wyjścia wezmą najdokładniejszą znajomość stanu faktycznego i działające, a umiejętnie przez nich zastosowane prawo. Przy tym wszystkim nadzwyczajna kurtuazja. Kurtuazja nie tylko w sądzie, lecz i w życiu prywatnym. [...] Skład personalny Sądu Okręgowego ustępował Sądowi Apelacyjnemu.

${ }^{57}$ LCVA, f. 129, ap. 6, b. 1465, Wykaz stanu służby Romana Wirszyłły, b.d., k. 37-38; Zob. akta osobowe Romana Wirszyłły - pisarza hipotecznego w Wilnie (LCVA, f. 127, ap. 7, b. 3263).

${ }^{58}$ Zgodnie z podaniem decyzją z 29 lutego 1924 r. „Dziennik Urzędowy Ministerstwa Sprawiedliwości” 1924, nr 7.

${ }^{59}$ LCVA, f. 129, ap. 6, b. 1465, Pismo sędziego Wirszyłły do prezesa Sądu Apelacyjnego w Wilnie, 27 X 1919, k. 3.

${ }^{60}$ LCVA, f. 133, ap. 2, b. 563, Wyciąg z protokołu z 5 listopada 1924 r., b.d., k. 20.

${ }^{61}$ Informacja przekazana autorce przez wnuczkę sędziego Wirszyłły - Janinę Wirszyłło. 
Oczywiście pod względem moralnym sędziowie byli bez zarzutu, ale pod względem dostatecznego zgłębienia faktycznego stanu sprawy, a czasami znajomości, rozumienia prawa i jego zastosowania, nierzadko pozostawiali wiele do życzenia" ${ }^{\prime 2}$. Takie zdanie na temat osób, w rękach których spoczął wileński wymiar sprawiedliwości, miał ówczesny obserwator sali rozpraw adwokat, później sędzia, uczestnik wojny polsko-bolszewickiej, oficer AK - Stanisław Mianowski. Na ile ocena ta dotyczy bohaterów prezentowanych szkiców — trudno rzec. Wszyscy bez wyjątku byli wykształconymi prawnikami, Polakami, którzy podjęli trud tworzenia na Wileńszczyźnie polskiego sądownictwa. I chyba zadanie spełnili choć dzieło zostało przerwane ponownym wkroczeniem bolszewików do Wilna latem 1920 r. - skoro inny świadek wydarzeń w swoich wspomnieniach pisał: „Gdy przyszły pierwsze wojska polskie na Białoruś, lud zwał je »pańskiemi« wojskami i wnosił, że ze strony wojsk tych odczuwać będzie może surowość, ale zawsze prawdę, uczciwość i sprawiedliwość. Tymczasem było inaczej. Przyszli potem polscy urzędnicy i przynieśli łapownictwo i nieład, jedne sądownictwo utrzymało się na właściwym poziomie i zyskało zaufanie ludności” ${ }^{33}$. Niewątpliwie, nie bez znaczenia, przy tym był fakt, że przedstawieni prezesi to „synowie tej ziemi" - Wielkiego Księstwa Litewskiego ${ }^{64}$.

\section{Bibliografia}

\section{Źródla}

Biblioteka Litewskiej Akademii Nauk im. Eustachego i Emilii Wróblewskich w Wilnie, f. 29.

Centralne Litewskie Archiwum Państwowe w Wilnie, f. 127; f. 129.

Mianowski S.: Świat, który odszedt. Wspomnienia Wilnianina 1895-1945. Oprac.

M. Parczewska, K.M. Mianowski. Warszawa 1995.

Woyniłłowicz E.: Wspomnienia 1847-1928. Cz. 2. Warszawa 2016.

${ }^{62}$ S. Mianowski: Świat, który odszedt. Wspomnienia Wilnianina 1895-1945. Oprac. M. Parczewska, K.M. Mianowski. Warszawa 1995, s. 169-170.

${ }^{63}$ E. Woyniłłowicz: Wspomnienia 1847-1928. Cz. 2. Warszawa 2016, s. 87.

${ }^{64}$ Fot. sędziów: Proniewicza, Zmaczyńskiego i Wirszyłło pochodzą z archiwów rodzinnych: Barbary Langiewicz-Mathis, Adolfa Zmaczyńskiego i Janiny Wirszyłło, za udostępnienie których autorka składa podziękowania, a sędziego Buyki — z LCVA, f. 127, ap. 7, b. 330. 


\section{Opracowania}

Bereza A.: Sądownictwo siedleckie. Tradycje i wspótczesność. Warszawa 2010.

Dąbrowski P.: Towarzystwo Miłośników Historii Reformacji Polskiej im. Jana Łaskiego - geneza, struktura prawna i działalność. „Odrodzenie i Reformacja w Polsce” 2017, T. 61.

Gierowska-Kałłaur J.: Władza sadownicza na terenie byłego Wielkiego Księstwa Litewskiego w czasach Zarzadu Cywilnego Ziem Wschodnich (1919-1920). W: Polska i jej wschodni sasiedzi w XX wieku. Studia i materiaty ofiarowane prof. dr. hab. Michałowi Gnatowskiemu w 70-lecie urodzin. Red. H. Konopka, D. Boćkowski. Białystok 2004.

Gierowska-Kałłaur J.: Zarząd Cywilny Ziem Wschodnich (19 lutego 1919—9 września 1920). Warszawa 2003.

Kalata K.: Zarzad Cywilny Ziem Wschodnich w latach 1919-1920. Struktura organizacyjna i zarys działalności. „Czasopismo Prawno-Historyczne” 2003, T. 55, z. 2.

Materniak-Pawłowska M.: Sadownictwa kresowego trudne poczatki (1919-1921). W: Studia z historii ustroju i prawa. Ksiega dedykowana Profesorowi Jerzemu Walachowiczowi. Red. H. Olszewski. Poznań 2002.

Materniak-Pawłowska M.: Ustrój sądownictwa powszechnego w II Rzeczypospolitej. Poznań 2003.

Mielcarek A.J.: Podziaty terytorialno-administracyjne II Rzeczypospolitej w zakresie administracji zespolonej. Warszawa 2008.

Petrusewicz K.: Dziesięciolecie sądownictwa polskiego na ziemiach wschodnich. Wilno 1929.

Solak Z.: Między Polska a Litwą. Życie i działalność Michała Römera 1880-1920. Kraków 2004.

Tarkowski M.: Adwokatura wileńska 1918-1939. Studium historyczno-prawne. Gdańsk 2014.

Wileński słownik biograficzny. Red. H. Dubowik, J. Malinowski. Bydgoszcz 2008.

Wileński stownik biograficzny: suplement. Oprac. M. Jackiewicz. Bydgoszcz 2012.

„Dziennik Urzędowy Ministerstwa Sprawiedliwości” [za lata: 1921, 1924, 1929].

„Dziennik Urzędowy ZCZW” 1919.

„Dziennik Wileński” [za lata: 1923, 1926].

„Palestra” 1936.

„Przegląd Notarialny” 1948.

\section{Źródla internetowe}

https://gdansk.gosc.pl/doc/1350339.Opowiesc-o-patriotach [dostęp: 6.03.2019]. 
Diana Maksimiuk

\section{Leitung des Bezirksgerichts Vilnius während der Arbeit der Zivilverwaltung der östlichen Gebiete - biografische Skizzen}

Schlüsselwörter: Vilnius, Gerichtsbarkeit, Richter, Zivilverwaltung der östlichen Gebiete

Zusammenfassung: Im November 1918 erlangte Polen die Unabhängigkeit zurück. Dies war jedoch Beginn des Aufbaus der Grenzen des wiedergeborenen Staates. Bevor das Vilniuser Gebiet im Jahre 1922 an Polen angeschlossen wurde, wurde die Macht über diese Region von 1919 bis 1920 durch die Polnische Armee und durch die polnische Verwaltung, die als Zivilverwaltung der östlichen Gebiete tätig war, ausgeübt. In ihrem Rahmen wurde die polnische Gerichtsbarkeit geschaffen, deren Funktionieren in der angenommenen Form den bolschewistischen Einmarsch im Sommer 1920 unterbrach und beendete.

Diana Maksimiuk

\section{The Management of the Regional Court in Vilnius in the period of functioning of the Civil Administration of the Eastern Lands - biographical sketches}

Keywords: Vilnius, judiciary, judges, Civil Administration of the Eastern Lands

Summary: In November 1918, Poland regained its independence. However, it was the beginning of building the borders of the reborn country. Before the Vilnius region was incorporated into Poland in 1922, in the years 1919-1920 the Polish Army and the Polish administration organised into the Civil Administration of the Eastern Lands exercised control over the area. Within its framework, the Polish justice system was created, whose functioning in its adopted form was interrupted and ultimately ended by the Bolshevik summer invasion (1920). 